\title{
EFFICIENCY CONCEPT REGARDING LAW ENFORCEMENT ACTIVITY BY THE PUBLIC AUTHORITIES
}

\author{
Elena Manțuc*, ORCID ID: 0000-0002-3649-4837 \\ Technical University of Moldova, 168 Stefan cel Mare Blvd., Chishinau, Republic of Moldova \\ *Corresponding author: Elena Manțuc, elena.mantuc@udu.utm.md
}

Received: 01. 10. 2022

Accepted: 02. 14. 2022

\begin{abstract}
A complex approach in the field implies exploring, on a theoretical level, of determining components which influence the efficiency mechanism of law enforcement activity by public authorities. Therefore, the objective of this article is to determine a coordinated and well-organized mechanism of law-appliance process, which would generate a higher efficiency of law enforcement activity by public authorities, as well as defining its concept. Thus, the implementation of the analytic method, along with the comparative one, led to a study of the highlighting various meanings of the notion of "efficiency", mandatory components of efficient law enforcement activity, distinguishing principles, such as general ones. As a result, the concept of Efficiency of law enforcement activity by public authorities was defined. Law-appliance efficiency is attained due to the qualitative achievement of the complete set of actions regarding application of law, thus, in case any of the constituent elements of this activity certain drawbacks are allowed, then even the most efficient and appreciated norm will not produce the necessary effect.
\end{abstract}

Keywords: law-appliance, public authorities, efficiency, concept, correctness, law enforcement, objective.

Rezumat. O abordare complexă în domeniu presupune o cercetare la nivelul teoretic al componentelor determinate, care influențează mecanismul eficienței activității de aplicare a dreptului de către organele autorităților publice. În acest context, scopul articolului este de a determina acel mecanism coordonat și bine organizat al procesului realizării prevederilor juridice, ce ar contribui la eficientizarea activității de aplicare a dreptului de către autoritățile publice și formularea nemijlocită a conceptului acesteia. Astfel, prin intermediul metodei analitice și celei comparative a fost realizat un studiu cu elucidarea diverselor interpretări ai termenului „eficiență”; componentelor obligatorii ale unei activități eficiente de aplicare a dreptului; evidențierea principiilor ca factorii principali ce influențează activitatea de aplicare a dreptului etc. Ca rezultat, a fost formulat conceptul Eficienței activității de aplicare a dreptului de către autoritățile publice. În urma celor relatate, concluzionăm că eficiența aplicării dreptului este obținută rezultatului realizării calitative a întregului complex ale activității de aplicare a dreptului, dacă într-un anumit element constituitiv al acestei activități 
se admit careva neajunsuri, atunci chiar și cea mai eficientă și reușită normă nu va aduce efectul necesar.

Cuvinte-cheie: aplicarea dreptului, autoritățile publice, eficiența, concept, corectitudine, aplicarea legii, obiective.

\section{Introduction}

Law enforcement activity is regulated within a permissive legal regime via imperative legal means of executive value and protection in a strictly determined manner. The legal aspect of law enforcement is reflected in law-appliance forms which make use of special procedural legal means of strictly formal nature. Such a formal way of law enforcement is directed, primarily, to ensure observance of participants' subjective rights and obligations in the field in compliance with material law norms, and secondly, to efficiently enforce lawappliance within strictly determined legal procedures and procedural norms in order to reach rapid and just solutions for legal issues.

In a democratic environment, application of law by public authorities needs to be both efficient and legal, and these characteristics cannot be accepted separately as they are indispensible. Thus, law-appliance efficiency cannot be favored to the detriment of legal standards.

The application activity is a means for achieving goals set for the law. Thus, "the goals of law-appliance activity, as mentioned by E.P. Shikin, are predetermined by the regulatory basis of legal regulations mechanism, which cannot have any goals disallowed by law" [1, p. 9]. Thus, law efficiency, along with law-appliance efficiency, are generally and specially correlated.

While exploring the concept of efficiency, it needs to be noted that it belongs to a number of more general and frequently-stressed features used in any field of social activity, is also applied in various scientific fields, and is part of politicians', sociologists', philosophers', and lawyers' vocabulary. The notion of efficiency is regarded by the contemporary doctrine as a relation between the obtained result and its grounds, and thus it is possible to compare the given result with the costs covered to reach it - economic efficiency, or with the envisioned goal - social efficiency [2, p. 29].

In legal literature, law efficiency is interpreted as regularity, correctness, promptness, reasonability, fairness of legal norms; law optimization; level of achieving necessary legal options; level of achieving legal provisions' objectives or relation between the de-facto outcome and the social goal for which law was passed; law enforcement activity, maximum use of all methods and means within the legal norms to fully achieve goals in legal practice, etc. The majority of authors who have studied this issue accept to determine law-appliance efficiency as the level of achieving the goals set by the legislator in respect to law, criminal charges, law enforcement activity [3, p. 121]. Law efficiency is its potential capacity. Due to this fact, it is worth discussing about its initial programming within the structure and direct objectives of the law. This very aspect, being a general feature, mandatory and permanent, stays unchanged and constant in both static and dynamic states, for the entire time period until the value of the law itself changes or becomes void.

Furthermore, any activity implies motion, evolution, and its success depends not only on law quality, but also heavily relies on possibilities and abilities of a given person (or group), in our case the subject of law-appliance, who creates the main element of law-appliance system. Of course, the potential of those dealing with application of law differs, thus the 
efficiency range of law-appliance is dynamic and by no means permanent, stable, or constant. The organic bind between law and law-appliance practice is described by the fact that "law and law enforcement authorities can be regarded as two models of interaction: logics and dynamics (of running, activity), each of them ensuring the other's activity" [4, p. 171].

Thus, law enforcement activity, along with application of a given law, also includes establishing of grounds for its application, carrying out a number of actions, methods and means to ensure exact and productive application of law. All of these are also linked with efficiency. Furthermore, their correct combination and choice will influence the efficiency of law-appliance in a given situation. With this is mind, it is safe to conclude that efficiency of law-appliance depends not only on special aspects of a given law, but also on the result of qualitative achievement of a complete set of actions related to law enforcement: should one constituent element of this activity lack sufficient quality level, allowing some omissions, then even the most efficient and elaborate law will not produce the necessary effect.

\section{Law-appliance mechanism as a general phenomenon}

The circumstances described above create grounds to consider law-appliance efficiency a more general phenomenon; these being the result of law efficiency and all means, methods, processes and forms executed by the subject who applies the law according to described activity. Thus, it is not a simple sum of terms, but rather an objective synthesis of possibilities which are interdependent and interconnected.

At the same time, it is wrong to draw an impractical line between law enforcement efficiency and law efficiency, or to opt for their absolutization. As elements, constituent portions of a whole - the entire law enforcement activity, they interact with each other. The unity of these concepts can be conveyed through the fact that both law efficiency and law enforcement efficiency are established as a result of analyzing and evaluating the same consequences, the factual modification caused by the application of law. Both the content of the law and law enforcement activity are aimed towards obtaining a result of maximal efficiency.

Thus, efficiency, as viewed from qualitative-quantitative standpoint, deals with the outcome of law enforcement activity by public authorities, which can be disclosed during practical and general theoretic research. Therefore, according to recommended notions for the concept of efficiency, one can distinguish three mandatory components:

1) objective set to be achieved;

2) costs related to achieving the objective;

3) activity's final result.

In other words, efficiency can be regarded as a certain consecutive order, in which the result defines activity's value, with the objective being the main initial concept that describes activity's trend and direction, while the final result is based on the initial objective [2, p. 31]. It must be stressed that the more successful the final result in the evaluation of law-appliance activity is, the higher is its efficiency level, and vice-versa. The objectives of legal regulations must be known not only to establish efficiency, but also to determine its level. Only by exploring the relation between law-appliance results and their direct objectives one can appreciate the efficiency of law enforcement activity. In legal literature it is mentioned that "Main measurement unit for evaluating law efficiency is that objective, for the achievement of which the law was passed" [5, p. 6]. 
In our opinion, such position is relevant for law enforcement activity. The efficiency of this activity derives from achieving its objectives because the foundation for law enforcement activity and also for that of law creation lies in strictly determined objectives, helpful to society and imposed by objective needs of social evolution. It is when a model or an ideal comes true that one can state that the positive effect was achieved: the more complete is achieving such a result, the higher is the efficiency. Efficiency level can be equally related to law and law enforcement activity. The reason behind it is that within law enforcement activity, the real values of the law are not denaturated, reduced, but rather an optimal version of legal means intervenes to bring along positive influence.

Laws are enacted for their further application. When elaborating laws, the lawmaker takes into consideration major social interests, aims to ensure a positive development of interpersonal relations, to protect social values [6, p. 175]. Laws are elaborated for their further application, thus there is the same intention of meeting major social interests, protecting established values and strengthening interpersonal relations by ensuring their enforcement by means of state guarantees [7, p. 107]. The three action categories of law (time, space and subject-oriented) define law efficiency, law in general, while the level of achieving the objective of legal enforcement is the result of social and politic influence of law, etc. Discordance among these criteria, urgent application of certain bulky legal norms of major importance may create multiple difficulties in public authorities' activity, while in solving certain practical issues there may appear unfavorable situations for a number of subjects of law, etc. [8, p. 253].

Law-appliance activity has its own objective, a rather determined one, and namely ensuring correct and timely application of the law that would suggest an optimal solution and a beneficial influence on adequate social relations. Thus, law-appliance activity has its specific objectives, which contribute to objective achievement for a given law, in conditions of private manifestation.

\section{Law-appliance efficiency}

The objectives which the lawmaker has to achieve are being legally materialized depending on the corresponding duties of public authorities. Thus, fighting crime and maintaining public order are part of the duties of preventing, investigating and discovering crimes. This objective, of current importance for the entire community, was attributed legal norms by the lawmaker and was allocated into duties of certain public authorities. For as long as this legal system is in force, we can discuss about law enforcement efficiency. In case of failure or lack of coordination of public authorities' activity with the new objectives, their activity with have a lower efficiency, namely the law-appliance activity, regulated by the bylaws of the abovementioned public authorities.

It is worth noting the complexity of establishing law-appliance efficiency by the public authorities. This is because the state mechanism has a complex structure, where each public authority has its own clear objectives; therefore, it becomes necessary to coordinate various objectives among each other, as well as with the common objectives of the administrative system in general. Thus, establishing hierarchy of objectives is one of the conditions of evaluating law-appliance efficiency. The objectives of law-appliance efficiency can be conventionally divided in social and legal ones, and they may not always coincide. Such a division, to some extent, will be a conventional one; however, with this in mind, it does 
considerably simplify solving issues related to separating legal and social efficiency of lawappliance activity.

During the evaluation of law-appliance efficiency one must also take into account quantity of resources used within the process of law-appliance (material, social, human resources, etc.) The concept of efficiency also implies a certain comparative element. At any time it is necessary to know which methods and means will generate the maximal result with a minimal input of resources. Therefore, it is relevant to include in the concept of law-appliance efficiency the element which determines the necessary means for achieving the objectives, and establishes the evaluation of obtained results in achieving them.

The means necessary to achieve the objectives are diverse. A part of them represent fund expenses, without them the concept of efficiency cannot correspond to its destination. Moreover, fund expenses must be directly proportional to achieved results, meaning that vital importance will be placed upon the principle of achieving maximal effect with minimal expenses. That is why, the economy, being a factor of choice "among the options granted by law" of the most reasonable and economically sound for the state means and methods for achieving legal objectives, must be viewed as an index of law-appliance efficiency. Therefore, the fewer the expenses and the better the results in such conditions, the more efficient will be the very activity of law-appliance.

Regulation will be more appreciated when contributing to or being directed to averting and excluding unjustified expenses. Law-appliance practice knows many such cases. There are also numerous cases when perspectives of law creation are determined by perspectives of bearing some excessive expenses, which go beyond admissible ranges. Of course, in such cases it is not advisable to merge or to correlate law efficiency and lawappliance efficiency [9, p. 135]. When examining, for instance, the field of criminal proceedings branch, quite often there will be situations when due to various non-objective reasons, repeated interrogations are allowed, thus parting away from procedural norms, along with experiments, searches, costly examinations, and also additional research and repeated legal examinations of criminal cases because of imperfections and mistakes made during the initial research. All of these situations cause material and spiritual expenses, and most often the fault lies on law subjects working on a given criminal case. The level of reaching objectives related to law adjustments can be rather high, however due to increased expenses during law-appliance process, it cannot be considered efficient.

When law-appliance activity lacks expenses, or when they do not go over acceptable limits (established by lawmaker), both law and actions are of equally high efficiency. In analogous situations, law efficiency unifies with law-appliance efficiency into a whole. Such a coincidence is not permanent, though the dynamics of any legal mechanism relies on a normal and productive functioning of its mechanism of influence, yet the study of lawappliance practice confirms the presence of some essential errors, which lead towards major discrepancies between law-appliance result and its objectives; and the larger this discrepancy is, the more inefficient law-appliance activity becomes as well. Lidia Barac states: "economy of law relies on correlation between the real achieved result and means used to achieve it (material resources, human and temporal resources)" [10, p. 62]. In the light of the aforesaid, it must be noted that in legal literature law-applience efficiency, most of the times, is a correlation between results of individual regulation and objective of law [2].

When evaluating law-appliance efficiency, one must note that some legal norms, laws are often directed towards achieving several objectives simultaneously. We may also 
encounter complex legal institutions, whose norms are directed towards a simple or complex objective, where stressing the objective of a certain legal norm does not make sense. In other words, law efficiency implies correlation between the done deed, meaning the achieved result, and the intended objective within the process of passing a given law. Thus, efficiency expresses the correlation between the real result and the objective of a given law. Sometimes, efficiency also means the level at which a subject follows the legal provisions contained in a law. From a theoretical standpoint, it allows us to better perceive the structure of law, its intellectual construction, while in practice, it contributes to the process of designing and elaborating law, making it lawmaker's duty to elaborate a law, whose content would aim to achieve, to the highest extent, the three distinctive qualities: efficiency, utility, and economy [10, p. 62 - 63].

In a way, it is possible to highlight law-appliance efficiency within inter-branch legal institutions, branch of law, legal institutions, and law-appliance efficiency of certain laws. However, law-appliance efficiency within a branch or legal institution is not simply equal to the sum of efficiencies of certain legal norms' application. State's main goals and objectives are recognizing, respecting and offering state guarantees on adhering to persons' and citizens' rights and obligations in compliance with the principles and norms unanimously recognized by the rules of international law, and pursuant to art. 1, par. 3 of the Constitution of the Republic of Moldova - "Governed by the rule of law, the Republic of Moldova is a democratic State in which the dignity of people, their rights and freedoms, the free development of human personality, justice and political pluralism represent supreme values that shall be guaranteed." [11]. Therefore, the above provisions must determine the functionality grounds for all branches of power, central and local public authorities. No public authority, no public servant is allowed to make a decision or to pass a normative act, whose content would contravene citizens' rights, freedoms, and obligations provided by the Constitution.

Another state's objective, which is also one of law-appliance efficiency, is ensuring the rule of law, being an objective and subjective state of social life, characterized by coordination, internal concordance; regulation of the system of legal relations based on normative provisions, principles of justice and legitimacy, as well as subjective rights, legal obligations and democratic, humanist, ethic and moral freedoms of all subjects of law. "The rule of law is the legal result the state tends to achieve." [12, p. 224]. It is the realization of law, which determines and regulates social life, the result of the manifestation of law and legality, as well as the will and the realized interests of the state power and of the society. The rule of law represents „the core of the social order, the fundamental condition of social equilibrium, the guarantee of realization of essential rights of society members and normal functioning of institutions." [13, p. 484]. An element of the rule of law is the rule of legal system. The rule of legal system does not exist without legality, and legality decreases when flaws appear in the rule of law.

When analyzing the role of law enforcement agencies, one must not overestimate and absolutize their place and role since the efficiency of these agencies depends on some objective conditions. "We notice that the rule of legal system is the final outcome of legality, that is, realization of and compliance with legal provisions. Namely the rule of legal system, or rule of law, is the objective of legal regulation, and namely, for its realization, laws and other normative acts are elaborated. The level of person's freedom, the level of ensuring 
observance of human rights, the level of democracy, etc., depend on the level of legality and rule of law" [8, p. 479].

It would be wrong to consider as efficient the law-appliance activity by public authorities in case the objective of the law is achieved by any means. The correct choice of methods is vital for the realization of legal regulation objectives, as well as for ensuring efficiency of law-appliance in general. Underestimation, wrong choice of methods, which have their origin in the normative basis of legal regulation, lead to errors in law enforcement, and to a decrease of law-appliance efficiency on behalf of public authorities [12].

\section{Law enforcement by public authorities}

As a result of doctrinal investigations carried out in the given section, here are some conclusions related to efficiency of the activity of law enforcement by public authorities.

Law-appliance efficiency is attained not just by following specific characteristics of legal norms, but is also the result of qualitative achievement of the complete set of actions regarding application of law, thus, in case any of the constituent elements of this activity lacks sufficient quality and certain drawbacks are allowed, then even the most efficient and appreciated norm will not produce the necessary effect. Therefore, in our opinion, the efficiency of the activity of law enforcement by public authorities is the level of realization of objectives the lawmaker sets for a norm, it being the quickest and the most complete achievement of results for a given law, legal institution, branch of law in relation with the intended objectives and goals set by means of passing and enforcing normative acts, provided that the principles of the activity of law enforcement are respected and that they are enforced effectively.

It is worth noting that the general principles of law-appliance, to a large extent, coincide with the general principles of law. In fact, the law is not a goal in itself, thus, it does not end at the stage of elaboration of legal norms, and is being realized in a complexity by means of principles which determine the activity of its appliance. Evidently, these principles coincide, both for the stage of elaborating law and for the stage of its application. For the activity of law enforcement in functional aspect, one can distinguish more special principles, typical for the regulation field and for the particularities of functionality of public authorities. Thus, research revealed the principles of institutional organization: a) principle of multilateral interaction and collaboration, b) principle of subordination, c) principle of economy; and legal principles of functioning of law enforcement activity by the public authorities: a) principle of objective research; b) principle of legality and reasonability of law application, c) principle of competence, d) principle of necessary regulation of the legal procedure, e) principle of individualization, f) principle of publicity, g) principle of rationality.

The analyzed principles of law enforcement activity have an interrelated connection, and, by disrespecting even one of these, the efficiency of law enforcement will be substantially decreased, it being a vital requisite of such activity. Along with complete and well-thought regulation of principles of law enforcement activity by public authorities, it will become possible to reach the highest level of efficiency for this process.

Therefore, while studying the efficiency of law-appliance activity, it is important to know which of the constitutive elements deliver positive results and which do not. It is also obvious that along with perfect functioning of law enforcement agencies, some branches of legal regulation may fail to react accordingly, and thus, lawmaker's intended result will not be achieved. That is why, without knowing the negative values and characteristics of all constituent parts, which form the law enforcement activity, it is impossible to create a clear 
presentation of efficiency of both legal provisions which are being realized and law enforcement activity in general.

\section{Conclusions}

In order to emphasize the law enforcement activity by public authorities, a key role is played by certain factors of both objective and subjective nature, which determine its presence. Their identification, their capitalization in organizing and functioning of public authorities, especially in the realities of the Republic of Moldova, orient us toward the theoretical, but especially practical implementation of an efficient law enforcement activity manifested by the public authorities. The efficiency of law enforcement activity is, in fact, the main indicator of organizing and functioning of public authorities, its essence being expressed by a certain comparative element. It is necessary to know which methods and means will determine the maximum result correlated to a minimum volume of consumed resources. It is, therefore, relevant, to include in the concept of law enforcement activity the element, which determines the mandatory means for achieving the objectives and establishes the evaluation of the results obtained in achieving these objectives.

In order to develop and to put into practice an activity of efficient application of legal norms by public authorities, it is appropriate to identify a system of factors which determine this efficiency. The number of highlighted factors does not need to be an exhaustive one as it shows a theoretical value of the phenomenon of efficiency of law enforcement activity, with practical realization, oriented towards establishing a real functional efficiency. Ensuring a correct realization of the highlighted factors coincides with the limits of a scientific project of increasing the efficiency of public authorities' activity. Analyzing the factors which cause appearance of deficiencies, it becomes necessary to look for and justify ways of improving law enforcement activity by public authorities. Taking into account that major reasons for committing mistakes are subjective, we believe that the benchmark would be the legal education of law enforcement subjects, developing for them a sense of responsibility for the decisions made, legality and fairness, and reliable attitude towards requirements of legal norms. This can be regarded both in a direct sense, that is, raising the standards of higher education, as well as the aspiration of the law enforcement officer to extend one's professional horizon, and also the prophylaxis of legal conscience, etc. The officer's interest in upgrading one's professional level could be triggered and streamlined by stimulating qualitative activity of law enforcement, such as introducing various rewards, but also by means of certain external factors, such as creating appropriate conditions (creating a favorable psychological environment, rationally organizing the work of law enforcement officers, using modern technical and scientific means and progressive experience, creating of computerized databases), as well as professionally recruiting candidates applying for a certain position; compliance of legal norms with the progressive development of social relations; properly organizing control over law enforcement activity (by the direct supervisors of law enforcement subjects, interdepartmental control, judicial control, etc.)

In the light of the aforesaid, we conclude that errors reduce the educational meaning of law enforcement activity and have a negative influence over the authority of subjects recruited for their expertise in the field. The negative result of the subject acting pursuant to the legal norm may create a misperception on citizens' behalf related to the orientation of the state apparatus as a whole, which will cause a significant decrease of the efficiency of law enforcement and discredit the involved public authorities. 


\section{References}

1. Shikin E.P.Osnovnie uslovia ăffectivnogo primenenie prava [Basic conditions for the effective application of law]. Abstract of the Thesis of legal science. Sverdlovsk: SJI - Sverdlovsk, 1971.

2. Negru A. Eficacitatea dreptului [The effectiveness of the law]. In: Administrarea publică [Public administration]. Chisinau, 2002, nr. 3, pp. 27 - 35.

3. Sherghin A.P. Savin M. la. Administrativno - iurisdictionnaia deiatelinosti organov vnutrenih del i puti povishenia eio ăffectivnosti [Administrative and jurisdictional activities of internal affairs authorities]. Moscow: Academy of the Ministry of Internal Affairs URSS, 1977.

4. Craiovan I. Un posibil ghid pentru cercetarea științifică în domeniul dreptului [A possible guide for scientific research in the field of law]. Bucharest: Pro Universitatea, 2013.

5. Samoshenco K.S. Izucenie ăffectivnosti deistviuisego zakonodatelistva [Study of the efficiency of curent legislation]. In: Sovetskoe gosudarstvo i pravo [Soviet state and law]. 1968, nr. 8, 3 - 10.

6. Popa N. Teoria generală a dreptului [General theory of law]. Bucharest: Actami, 2000.

7. Popa C. Teoria generală a dreptului [General theory of law]. Bucharest: Lumina Lex, 2001.

8. Avornic Gh. Teoria generală a dreptului [General theory of law]. Chisinau: Cartier, 2004.

9. Negru A., Zaharia V. Teoria generală a statului și dreptului în definiții și scheme (note de curs) [General theory of state and law in definitions and schemes (course notes)]. Chisinau: State University of Moldova, 2009.

10. Barac L. Elemente de teoria dreptului [Elements of law theory]. Bucharest: ALL Beck, 2001.

11. Constitutia RM from 29.07.1994 [The Constitution]. In: Oficial Monitor 12.08.1994.

12. Fiodorov G. Politica, gosudarstvo, pravo [Politics, state and law]. Chisinau: CEP USM, 2016.

13. Negru B., Negru A. Teoria generală a dreptului și statului [General theory of law and state]. Chisinau: Bons Ofices, 2006. 